\title{
THE TRIBES IN THE CONTEXT OF THE DIGITAL TECHNOLOGICAL HYBRIDISM: THE CONSTITUTION OF THE VIRTUAL DIGITAL ACQUAINTANCESHIP
}

\author{
AS TRIBOS NO CONTEXTO DO HIBRIDISMO TECNOLÓGICO DIGITAL: \\ A CONSTITUIÇÃO DA CONVIVÊNCIA DIGITAL VIRTUAL
}

\section{LAS TRIBUS EN EL CONTEXTO DE LA HIBRIDACIÓN TECNOLÓGICA DIGITAL: LA CONSTITUCIÓN DE CONVIVENCIA DIGITAL VIRTUAL}

Luciana Backes

Cleber Gibbon Ratto

\begin{abstract}
The article approaches the graduation of the educator in the contemporaneity, investigating the processes of teaching and learning through emerging digital technologies (DTs). We can understand the DTs as acquaintanceship spaces, while they enable the representation of the perception about the knowledge, the dialogical relationship and the interaction among participants. In other words, thinking the human being regarding the other and in congruence with the space, in order to get to know the object. The problem includes two aspects: the context of the digital technological hybridism and the constitution of the virtual digital acquaintanceship. The reflection about this problem took place during the initial graduation courses of the educator, developed in Brazil and in France, having as an initial goal the interaction between subjects (graduating educators) and the object (digital technological hybridism) in the educative space. The empirical data resulted from the process of interaction and representation of perception of the participants in the proposed activities. We submitted the data to the methodology of content analysis. Thus, in the research, we evidenced that the constitution of virtual digital acquaintanceship occurs through thrilling encounters, the aesthetics that founds the "tribes"; the daily "being-together" that is established in sociality and otherness; the dialogical relationships in the interaction processes; the structural coupling established in acquaintanceship. Therefore, we believe that in the educational context, the development of problematizing (disturbance) pedagogical practicing of the daily living and living together is important, in congruency with the DTs that potentiates the interaction.
\end{abstract}

KEYWORDS: Graduation of the educator. Digital technological hybridism. Emerging technology. Digital virtual acquaintanceship.

\section{RESUMO}

O artigo aborda a formação do educador na contemporaneidade, investigando os processos de ensinar e de aprender por meio das tecnologias digitais (TDs) emergentes. As TDs podem ser compreendidas como espaços de convivência, na medida em que possibilitam a representação da percepção sobre o conhecimento, a relação dialógica e a interação entre os participantes. Ou seja, pensar o ser humano na relação com o outro e em congruência com o espaço, para conhecer o objeto. A problemática contempla dois aspectos: o contexto do hibridismo tecnológico digital e a constituição da convivência de natureza digital virtual. A reflexão sobre problemática ocorreu durante os cursos de formação inicial do educador, desenvolvidos no Brasil e na França, tendo como foco principal a interação entre os sujeitos (professores em formação) e o objeto (hibridismo tecnológico digital) na reconfiguração do espaço educativo. Os dados empíricos resultaram do processo de interação e representação da percepção dos participantes nas atividades propostas. Esses dados foram submetidos à metodologia de análise de conteúdo. Dessa forma, na pesquisa, evidenciamos que a constituição da convivência de natureza digital virtual ocorre por meio: das relações de emocionar, a estética que funda a "tribo"; do "estar-junto" cotidiano que se instaura na socialidade e na alteridade; das relações dialógicas nos processos de interação; do acoplamento estrutural estabelecido na convivência. Assim, acreditamos que no 
contexto educacional, é importante o desenvolvimento de práticas pedagógicas problematizadoras (perturbação) do viver e conviver cotidiano, em congruência com as TDs que potencializam a interação.

PALAVRAS-CHAVE: Formação do Educador. Hibridismo Tecnológico Digital. Tecnologia Emergente. Convivência Digital Virtual.

\section{RESUMEN}

El artículo analiza la formación del educador en la contemporaneidad, la investigación de los procesos de enseñanza y aprendizaje a través de tecnologías digitales (TDs) emergentes. Las TDs pueden ser entendidas como los espacios de convivencia, en la medida que permiten la representación de la percepción del conocimiento, la relación de diálogo e la interacción entre los participantes. Es decir, pensar el ser humano en relación con el otro y en congruencia con el espacio para conocer el objeto. El problema incluye dos aspectos: el contexto de la hibridación tecnológica digital y la constitución de la convivencia de naturaleza digital virtual. La reflexión sobre el problema ocurrió durante los cursos de formación inicial de educadores desarrollados en Brasil y Francia, centrándose principalmente en la interacción entre sujetos (formación del profesorado) y el objeto (la hibridación tecnológica digital) en la reconfiguración del espacio educativo. Los datos empíricos resultaron del proceso de interacción y la representación de la percepción de los participantes en las actividades propuestas. Estos datos fueron sometidos a la metodología de análisis de contenido. Por lo tanto, en el estudio, se observó que la constitución de la convivencia de naturaleza virtual digital es a través de: la relación de emocional, la estética que funda la "tribu"; el "estar-junto" en el cotidiano que establece la sociabilidad y la alteridad; las relaciones dialógicas en los procesos de interacción; el acoplamiento estructural establecido en la convivencia. Por lo tanto, creemos que el contexto educativo, es importante desarrollar prácticas pedagógicas centrada en la resolución de problemas (perturbación) cercanos al vivir y convivir cotidiano, en congruencia con las tecnologías digitales que potencian las interacciones.

PALABRAS CLAVE: Formación de Educadores. Hibridación Tecnológica Digital. Tecnología Emergentes. Convivencia Digital Virtual.

\section{INTRODUCTION: ACADEMIC GRADUATION OF THE EDUCATOR}

The article discusses about the academic graduation of the educator in contemporaneity, investigating the teaching and learning processes through emerging digital technologies. The named emerging digital technologies are the new DTs incorporated by the human beings in daily living and living together. Thus, the new DTs, which are extensions of human beings, launched for specific use and which are not part of the daily routine, are not considered emerging digital technologies. The adjective emerging is linked to the idea of emersion, that comes to surface, that leaves the interior towards the exterior, because of that, we connected the adjective emerging to the daily routine, to socialization and to common sense, that is, it is no longer in the deep, inward, safe and with little access to.

In the context of the article, we can understand DTs as acquaintanceship spaces according to Backes (2011), while they enable the register of the perception about the knowledge, the disturbance in sharing with the other, the interaction and the dialogical relationship among participants. In other words, thinking the human being regarding the other in daily living and living together in spaces that are virtual digital. The virtual digital acquaintanceship space is set in this interaction between subject (human being) and the object (virtual digital space). For Latour (1991), in this interaction, either subject or object is equally strong and real while they act over each other. The idea of agent is that person or that thing which makes the other do. 
The reflection is established through the following point: "how do we institute the virtual digital acquaintanceship in our daily routine?" That question emerged during the graduation course of educators, in which the researcher and author of this article was a professor, and in sharing this experience with other researchers.

The graduation courses of the educator took place: in complementary activities "Learning in Virtual Worlds" and "Pedagogical Practices in Virtual Worlds" (Brazil), in directed work "Analyse du travail et Polyvalence" (France). The courses offered in both countries were developed in the context of the digital technological hybridism set by DTs such as Learning Virtual Environment, Instant Communicator, Social Media, Metaverse and Blog. The empirical data used for the reflection of the problem were the register of the perception of graduation educators, through the interaction process, done during the activities proposed in the courses, in congruence with virtual digital spaces (DTs). The qualitative data were treated using the content analysis, according to Bardin (2011), by three parts: a) preanalysis; b) material exploration; c) treatment of the obtained results and interpretation.

The analyses are built from the understanding of living and living together of human beings in contemporaneity, that also occur in virtual digital spaces set through DTs. In the setting of virtual digital spaces, it is possible to identify the constitution of another kind of acquaintanceship among human beings, with virtual digital features. Thus, it is possible to highlight the aspects implicated in the constitution of the virtual digital acquaintanceship.

\section{LIVING AND LIVING TOGETHER IN CONTEMPORANEITY}

The living and the sharing living with the other, that is, the acquaintanceship, in the contemporary world according to Maffesoli (2013), implies a "dynamic rooting", characterized by the need: of sharing emotions, of living together (origin) and of technological development (future). Thus, the "dynamic rooting", that seems paradoxical in the perspective of progress, becomes viable in the perspective of ingresso (Latin). "Ingress in this world" (Maffesoli, 2012, p.83). Therefore, there is not an end of the archaic (origin), to begin the technological (future), as announced in a progressive logic, but in a complex relationship in the synergy between the archaic and the technological development.

In this perspective, the human beings and the technique are in complex relationship, that is, in interaction, contradiction, modification, resulting in a spiral movement. According to the understanding of Maffesoli (2005, p. 136-137),

[...] regarding to the Internet, I hear about comments that are because the greatest categories that arrange the nets are fluid. However, life is not steady. Therefore, in my opinion, those dogmatic comments that pre-defined the social order and a rationally framed life, unmask themselves. My theoretical sense leads me to observe with generosity what is born as expressions of life. Moreover, it is understood that this vitalism or this vitality rely, effectively, on the technological development. 
In this perspective, we consider the coexistence between real geographic and located and real virtual digital, human being and technology, past and future. The coexistence between geographic space and the virtual and digital space is evidenced in researches developed in education processes, through the context of the digital technological hybridism (Backes, 2011, 2015), of interstitial spaces (Santaella, 2010), informative spaces (Lemos, 2008), of hybrid spaces (Souza e Silva, 2006). However, this hybrid, evidenced in researches, goes beyond the coexistence of the units mentioned above, it consists in the mixture, articulation among them in such a way that cannot be explained without the other, according to Latour (1991). We opted for the concept of net: flexible, historical, confusing. This hybrid is not a theoretical creation or construction; it is an observation of the daily routine in constant redefinition of space and people, according to Latour (1991). The redefinition is in the association, in the connection, in grouping between space and people, in order to reset the world in which we are able to cohabit with other beings.

Thereby, the educational context is also people's daily lives and not an exterior instance. Whenever we approach the teaching and learning processes and the academic graduation of the educator, we are dealing with daily life and its complexity. Therefore, we understand that:

\begin{abstract}
In the logic of the net, the attraction and repelling process will happen by choice. It is possible to watch a sliding from the logic of the identity to the one of identification. Here, the affective warm is highlighted or, at least, its place in social structure is acknowledged. Beyond the egalitarianism and the social contract, there is a 'concentric' perspective of the sociality, which means that the different circles that compose it adjust to each other and are only valid while connected. Therefore, the Estate for Hegel is a kind of communnitas communitatum; individuals are not the first, but their relationships. This idea of interconnection is remarkable because it privileges the role of the cement that can perform the affective.
\end{abstract}

When altering the dichotomic logic established between human/technique, natural/cultural, real/virtual, for a logic of net and interconnection, privileging the interactions, we realize that "this state of dynamic balance, this conflictual harmony, creates a constructive and harmonious disarray" (Maffesoli, 2005, p.134). Therefore, we have a virtual reality and a real virtuality that emerge, as Castells (2003) proposes.

In the present days, we are able to face new ways to establish social bonds. Regarding to Maffesoli (2000), society has been articulating itself through behaviors in which the "ethos", the affection and emotion are considered key elements in the reconstitution of the aggregations throughout the communities. Those communities have constituted themselves of different manners and in different dimensions through social media and virtual learning environments, defined as virtual communities (learning, practicing and relationships). For Schlemmer, Malizia, Backes and Moretti (2012) the virtual communities arise from the need of insertion, updating and social reorganization, through action, interaction and sharing.

This way back to communitarian is defined by Maffesoli (2005, p.130) as tribalism, which movement states meaning to the importance of the social existence. Thus, "[...] a 
recomposition of the social bond and to that could simply define as the "being together" which characterizes social life".

Thus, the trend of the more individualist, rational, grounded in contractual groups and with cultural, productive, sexual and ideological domains modern society named by Maffesoli (2005) from social, becomes to be understood through post-modernity, inserted in the context of masses, population, in which people play different roles, through affective tribes, named by Maffesoli as sociality (2005, p.132). In sociality

\begin{abstract}
the person (persona) plays roles either within their professional activity or within the different tribes in which the person takes part. Their costume changes, the person follows their taste (cultural, religious, sexual, social...) taking their part each day in the several games of the Theatrum mundi.
\end{abstract}

We realize that social relationships constitute in the return of multiplicity, of coexistence and plurality a return of the emotion, of 'magic', of affectionateness.

Therewith the relationship is established through tactile communication, where we touch the other through the word or the image, so that the other share their thought, their objects, ultimately, their life, the same way I share my thought, my objects and my life. Therefore, there is room for generosity and solidarity for the construction of social life. Nevertheless, social life is also constituted in virtual digital spaces.

We are in the world with the other and for the other, establishing different social bonds by the desire of "being together", in communion, sharing with the other, in congruence with the different spaces we set. The living and living together, take place in this systemic context, where people, objects and the segments are related, articulated and imbricated. The living together movements are dynamic - subject/object, culture/nature, objective/subjective, sense/emotion; hybrid - mixture in such a way that one cannot be explained without the other; complex - complementary and antagonistic at the same time. It is impossible to measure or define this dense reality, in which we live in contemporaneity. Maybe, we could characterize it, reflect about it, and identify aspects...

In this reality, the living together among people in different nets (geographically located and virtual digital) enables the sharing with the other. It develops intense, lasting, shallow and ephemeral social bonds. The emergency of diversity and of differences emerges at the same time of intolerance. The communication among people in a more heterarchical relationship as well as manipulator by the interests of those who communicate; the construction and reconstruction of culture; the possibility of being author and co-author in the world where we live.

Thus, in order to be able to think the tribes as new way of social organization through the "ethos" (the affection and the emotion) in the context of the digital technological hybridism, we build the problem that consists in, "How do we constitute virtual digital acquaintanceship through registers expressed in virtual digital spaces?" 


\section{DIGITAL TECHNOLOGIES: VIRTUAL DIGITAL SPACES}

The DTs are hardware and software such as virtual learning environment, instant communicator, game, simulator, weblog, wiki, electronic mail, communicative agent, and social media and the emerging digital technologies - environment in virtual reality, metaverse (3D virtual digital world) and wireless and mobile technologies. As well as, they are peopleware: virtual community of learning, of practicing and of relationship and/or social networking.

The concept of virtual digital space, according to Backes (2011), is a reframing of the concept of space built by Santos (1980). Therefore, the virtual digital spaces are the configurations drawn in the relations and in the interactions that happen through digital technologies, in daily living and living together. So, from the daily routine, the different DTs are inserted in the educational context, in graduation courses for educators, with the purpose of setting the virtual digital spaces.

The virtual digital spaces, according to Backes (2011, 2013, 2015), are set by digital technologies that enable: the register of human beings perception, the action and interaction of all involved as well as the expression of disturbances of conflicts, of differences and of diversity. That occurs through hierarchic relationships - the participants do not need to ask for authorization to express themselves or propose a discussion. Thus, not all DTs can be considered virtual digital spaces and not all virtual digital spaces can be understood as cyberspaces. The cyberspace, in a broader perspective, according to Lemos (2007, p.74):

\footnotetext{
[...] is not only a commutation space. Samples pullulate in this sense: chats, muds, forums, newsgroups. All of them with most diverse contents (academic, erotic, revolutionary, marginal, politic or leisure). The cyberspace is not the desert of the real, as well as it is not the end of the communication or the social. The same way, the computer viruses, as well as hackers piracy are strong expressions of this techno-social improvisation.
}

The DTs, as an expression of this daily living and living together, are usually used in an articulated way, setting the hybridism among the technologies, that is, a set, a mixture and an articulation. In the daily routine, people use, at the same time, social media, electronic mail, instant communicators. That articulation takes place naturally through links that enable people's mobility among the DTs during its usage, causing an impression of a unique technology, integrated and articulated in such a way that the actions only take place within this set. We shall take an example the cellular phone with its set of applications. We call someone, then we send a file that person requested, we publish on social media the information resulting from that interaction and we can also communicate the WhatsApp group the decisions made in that interaction. 
This daily routine is also evidenced in graduation courses for educators. That is, we use the learning virtual environment, wiki or blog, which are eventually complemented with the creation of groups in social media, contacts via instant communicator, naturally performed by students and proposed by them in the pedagogical practice. Therefore, the context of digital technological hybridism emerges from this routine. That fact occurs because the different DTs enable participant's action and interaction of several ways and several languages, considering the same subjects, topics and comments.

This way, we create and recreate a hybrid context, that is, the context of the digital technological hybridism, which interfaces can be the most varied regarding the figures that follow.

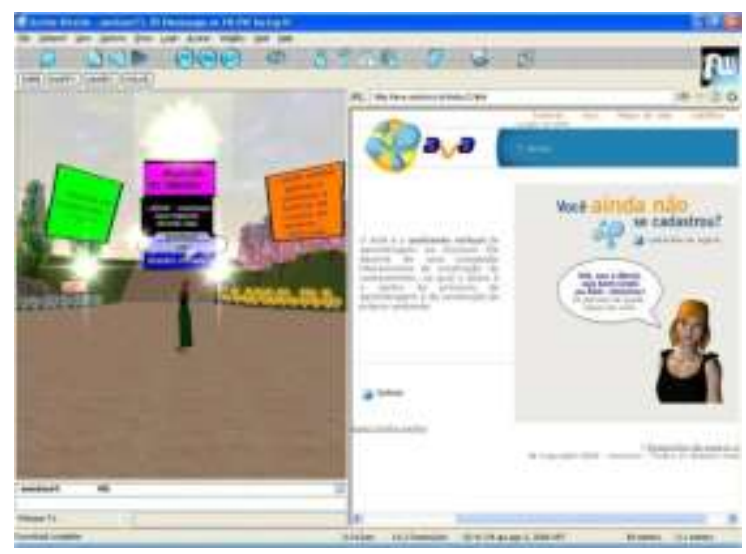

FIGURE 1 - Hybrid among metaverse, learning virtual environment and communicative agent Source: Backes (2011)

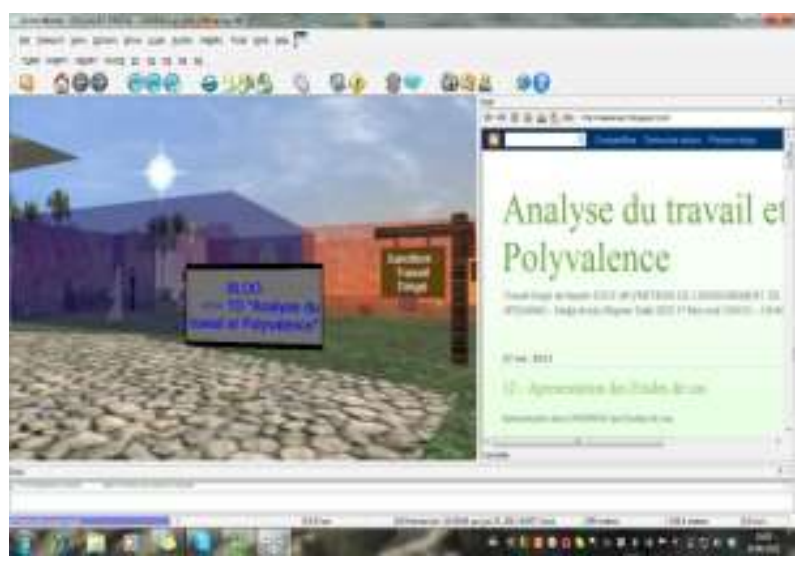

FIGURE 2 - Hybrid among metaverse, learning virtual environment and communicative agent Source: Backes (2011)

The context of the digital technological hybridism takes place in the combination, articulation and integration of different DTs (virtual digital spaces), which are used for the development of teaching and learning processes, an adaptation from the daily living and 
living together to the educational context. The constitution of the virtual digital acquaintanceship takes place in this daily living and living together, among human beings in virtual digital spaces.

The composition of the digital technological hybridism is singular and unique to each group that sets its living in these virtual digital spaces, because they emerge from the daily routine. The combination, articulation and integration of different technologies, implies the students' familiarization regarding the DT, the infrastructure of the universities regarding the technological apparatus and the pedagogical practice used for teaching and learning process. It is important to remind that the meanings are built in the interaction among human beings, through DT, pedagogical practice and the ways of acquaintanceship in the community (tribe).

The digital technological hybridism is comprehended by digital technologies previously selected and, in its usage; the participants along the graduation incorporate other DTs. In this context of digital technological hybridism, it is important to highlight the novelty, not regarding the technologies inserted, but the novelty as Hugon (2011, p.68) suggests, "It is here that the novelty point is established, that shall be approached by us in an inverse way. A simple technical object does not have any value here since a certain critical mass of users will not have recovered it, in order to sanctify as an object in that group recognized."

Therefore, we advance in understanding about teaching and learning processes in the context of the digital technological hybridism, in order to contribute in reflections referring to the constitution of a virtual digital acquaintanceship. The novelty is not on the set of the virtual digital acquaintanceship, but in the meaning assigned and in the actions performed by users in congruence with virtual digital space.

\section{THE CONSTITUTION OF A VIRTUAL DIGITAL ACQUAINTANCESHIP}

The acquaintanceship is the human being living shared with the other, which is established in different spaces and in different ways. To Maffesoli (2004) the human being exists when the look and the spirit of the other notice him, in the otherness perspective. Therefore, the human being begins to exist for the other and through the other. Thus, to set the acquaintanceship it is necessary that the essence of the relationship happen in the thrilling. The thrilling, for Maturana (1993, p.34), consists the action of non-indifference from one human being to the other, that is,

The one who accepts the other in their existing space and does not denies their legitimacy. The one who encounters the other in the dignity of that other. Moreover, in the moment I encounter the other in their dignity, the other encounters me in my dignity. In the moment I respect the other, the other respects me. 
The thrilling is evidenced in the action of the human being always towards the other. To Maffesoli (2000) the "me" and the "us" emerge in the daily interactions, through emotional bonds. What we think, the values, our character are linked to our living in community, or tribe to which we belong. The human being transits among several tribes and communities, establishing affection bonds, through the feeling of belonging. To Maffesoli (2001) the emotional and the affection are dimension of the acting regarding the spirit.

However, we evidenced relationships among human beings that happen from oppression, exclusion, submission, indifference, and marginalization. Those relationships do not happen in the interaction between "me" and "us", there is a "me" that is bigger than the other "me(s)", therefore there is not "us". In those situations, there is no acquaintanceship because there are no sharing.

In present days, we live a whirl of experiences, potentiated by DTs that make different kinds of acquaintanceships emerge. The reflection on the virtual digital acquaintanceship comprehends rethinking, like that, the education and the graduation processes of the educators using DTs, because the relationships promoted in those spaces are mediatized ${ }^{1}$ by culture nets constituted in this virtual digital acquaintanceship. Thus, the graduation of the educator does not happen in the perspective of learning about the DTs, even because its development is so fast that soon are outdated, and neither it happens in a perspective of how to use them in the pedagogical practice. However, how they learn knowledge in a methodological and epistemological perspective, through DTs, that is, learning how we learn through DTs.

To Maturana and Varela (2002) the constitution of the human being does not take place in any relationship, but in relationships of love, in which the other arises as legitimate in the acquaintanceship, so, there is no difference. Therefore, all recognize the other with whom we live during the graduation course. According to Maffesoli (2006), when we accept the other there is a feeling of bothering in taking part of their existence, following, enjoying, very different from controlling the other.

The pedagogical practice proposed in the graduation course actualizes through relationships and interaction, feeding the flow among participants for the knowledge building.

According to Maturana (1999) all the human relationships are social relationships and those relationships are supported by the thrilling. The thrilling that gives the character and the supporting is the love. In this sense, the virtual digital acquaintanceship can actualize in the desire of being together, in the emotional bond (reliance), in the heterarchical relationships among human beings, through mutual respect and mutual acceptance.

\footnotetext{
${ }^{1}$ Mediatization is the characterization of the pedagogical mediation that consists a "[...] communication, conversational process. A process of co-construction of meanings, which goal is to open and facilitate dialogue and to develop a meaningful negotiation of processes and contents to be worked in educational environments, as well as to encourage the building of a relational and contextual knowledge, generated from the professor/student interaction." (MORAES, 2003, p. 210).
} 
The interaction flow is kept during the graduation course of the educator in congruence with the DTs that compose the context of digital technological hybridism. Thus, in the metaverse, in which human beings are represented by avatars and use different languages to communicate, we can have a notion of the flow that feeds the tribe, because there is horizontality in the relationships, the sharing of what each one knows and they all together reflect about the kinds of knowledge in a creative, playful way. According to figure 3 , this was captured during the graduation of educators, using the metaverse for interaction.

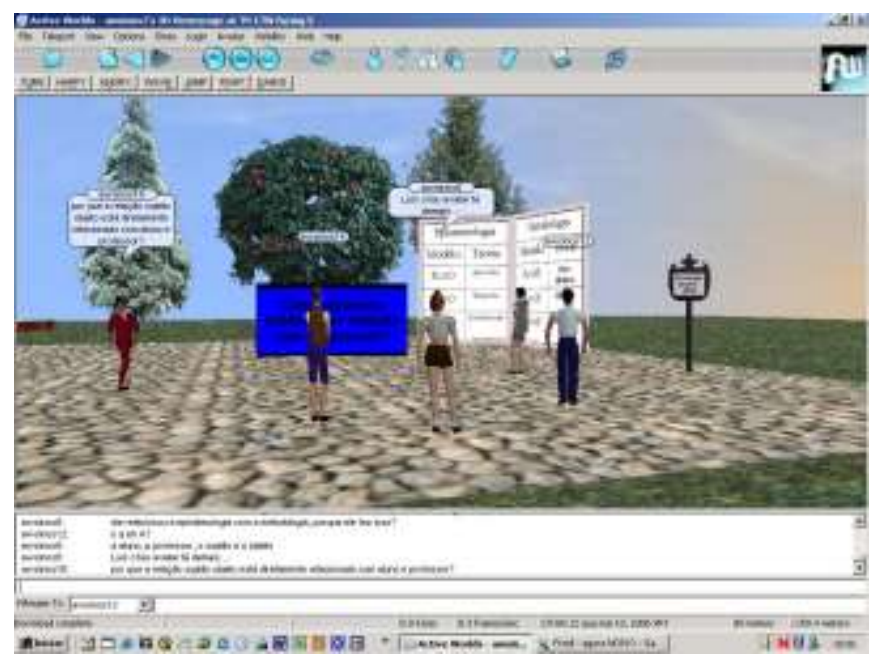

FIGURE 3 - Interaction in metaverse, through avatar Source: Backes (2011)

To Costa (2008), the thrilling in relationships among human beings in virtual digital spaces is evidenced as well as in geographic spaces. The virtual digital space "is constituted as space that enables the thrilling while it is an environment for relationships, in which individuals meet, talk, learn together, in the sense that Maturana gives to Thrilling as a flow of a domain of actions towards the other in the dynamic of living" (p. 156).

The domain of the means takes place in the interaction between the human being and the social system (others), in a recursive ${ }^{2}$ way and in congruence with the space. Therefore, we constitute two kinds of systems: closed (human being) and open (social), being the learning (closed) and the knowledge construction (open). This way, when dealing with individual phenomena, we broaden the understanding of social phenomena and vice-versa.

The interaction takes place in communication, in language and the central focus of language is reflection and self-consciousness. Through language it is possible to access the perception of the human being, what enables the human being to take consciousness concerning to himself and to the other. To Maffesoli (2011, p. 26) "What prevails is the community pulse, potentiating the doing, the being, the thinking like the other, and above all this, for the other".

\footnotetext{
${ }^{2}$ In the recursion, an operation is applied over the result of the operation previously performed, different from the repetition, that consists an operation applied over the same factor.
} 
The relationships among human beings in a community, wanted in the educator's graduation course, take place through the dialogical relationship, that is, "Through dialogue, reflecting together about what we know and what we do not, we can critically act to transform reality" (Freire and Shor, 1992, p. 123). Within the educational context, the dialogical relationship does not happen with a directive educator, but among human beings who share living with the other in a solidary, critical and creative way.

The construction of knowledge can occur through the dialogical relationship, because in this relationship we share our understandings, we ask questions and problematize and the human being is propelled to act in a reflexive way, revealing new learning. Thinking is related to the story of species, each one's story of life and the actions performed in different tribes. We, human beings, are social beings because we live constantly in interaction and regarding the other. The relational scope happens through individual phenomena, as autopoietic $^{3}$ beings, and the social phenomena, through the structural coupling, in a perspective that is not contradictory, but complementary.

According to Maturana and Varela (2002, apud Backed, 2013, p.343) "The structural coupling consists in mutual modifications among human beings, that is, the autopoietic units that are in interaction process, and the environment. In the interaction, the autopoietic units change, but they do not lose identity along the process".

In this sense, whenever there is an interaction process in which human beings and the environment change, there is structural coupling. Therefore, interaction is fundamental so that the human being becomes conscious of their presence in the world and the presence of the other, that is, in sharing the presence, we can have the co-presence. According Lévy and Lussault (2003) the co-presence is characterized by the set and aggregation of distinct social realities, in the same space. Thus, in the co-presence the degree of distance among human beings is equals zero. The co-presence density varies according to space situation and interactions established.

A social system is constituted in the recurrence of interactions that result in the coordination of its members behaviors, regarding Maturana (1999). This way we can say the recurrence takes place in cooperative interactions and, consequently, the virtual digital acquaintanceship is constituted in the structure of social systems, that is, to create a collective body, establish the ethos, create bonds, being together. To Maffesoli (2000), the ethos is the world understanding of a collective; the interpretation we give to our daily routine.

The virtual digital acquaintanceship takes place when human beings mobilize the thrilling through sharing their perceptions, the disturbance caused by the other or by the environment, the recursion, as it builds relational domain in a responsible way and the dialogue. Besides that, they reflect together about what they know, what they do not know and what they would like to know in their interaction processes in virtual digital spaces. In

\footnotetext{
3 To Maturana and Varela (2002) the autopoietic beings are the producers and the product at the same time, being and doing are inseparable, that is, they produce, perform and specify themselves.
} 
the graduation of educators, these actions are lived in discussion forums proposed in the learning virtual environment, in comments posted on blog, among other virtual digital spaces, as can be seen in figures 4 and 5 .

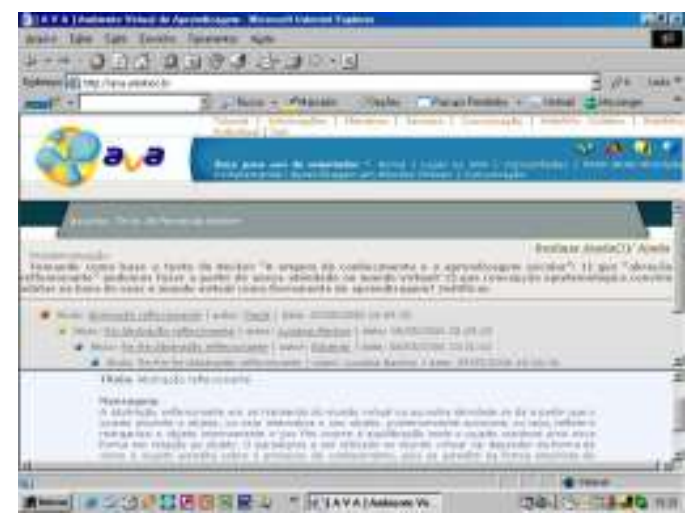

FIGURE 4 - Record on forum of the learning virtual environment.

Source: Backes (2011)

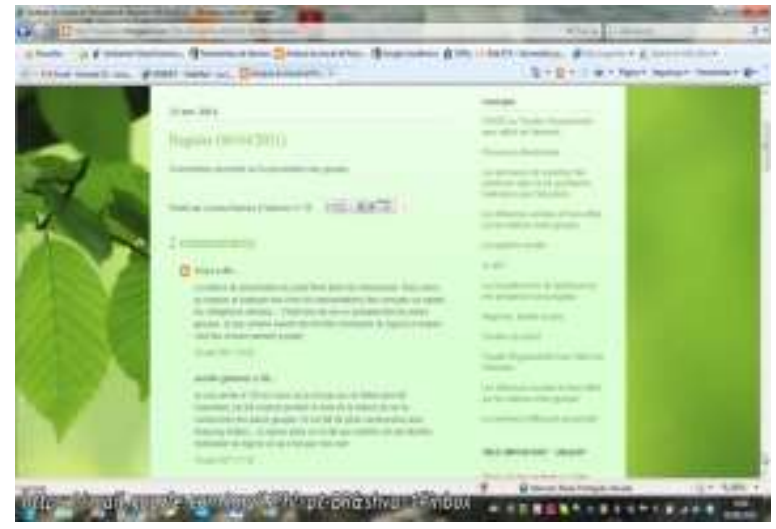

FIGURE 5 - Record on comments of blog Source: Backes (2011)

Those relationships actualize in a heterarchical acquaintanceship and of sharing of perceptions in virtual digital spaces. Thus, human beings establish proper $^{4}$ behavior for this social system, which become consensus in acquaintanceship until the moment they are no longer wanted or do not answer the needs of the community. It is then that, through disturbance, they define and redefine consensual behaviors in a in a dynamic way.

\footnotetext{
${ }^{4}$ To Maturana (2002), proper behavior actualizes when the human being recognizes the domain of action of the other, that is, the knowledge expression.
} 


\section{CONCLUSION: THE VIRTUAL DIGITAL ACQUAINTANCESHIP IN THE GRADUATION OF THE EDUCATOR}

In the analysis of the empirical data, through the content analysis method, it was possible to find that the constitution of the virtual digital acquaintanceship implies a thrilling relationship, an aesthetics that founds the tribes, a dialogic relationship during the interaction process, the daily "being-together" and the structural coupling established in the acquaintanceship. That thrilling is what legitimates the other as someone with whom I can learn. The aesthetics founds tribes when sharing emotions and passions. The daily "beingtogether" that is established in sociality and in otherness and in which the relationships are heterarchical and boundaries are permeable according to Latour (1991) dissolving the distinction between subject and object. The dialogical relationship during the interaction process; and the structure coupling established in the acquaintanceship, transforming subject and object, in congruence with virtual digital spaces. In virtual digital living together, the relationship between person and technology is not based on using, disusing and abusing, but on congruence, sensibility, intelligence and recursion.

The education context, along history, was developed in an individualistic, objective and Cartesian perspective. We format, human beings for them to be individuals, with identity and that take part in a society in a dichotomic relationship between subject and object. Therefore, in order to be able to change that logic of the education context and build logic in the perspective of subjective and complex people, we need to share the living with the other, that is, to build acquaintanceship in congruence with space, in a recursive relationship between subject and object, building nets. For Latour (1991) multiple connections, stablished with other entities, which act and interact among each other compose those nets. Therefore, we believe that in the education context, especially in the graduation of educators, the development of pedagogical problematizing (disturbance) practices of daily living and living together is important, congruently with the DTs that potentiate interaction among human beings.

Therefore, the teaching and learning process takes place in a broad and systemic hybridism - because professors, students, DTs, classroom, pedagogical practices and knowledge are in congruency - and complex - because each time fewer we can distinguish what concerns: to geographic space (classroom) and virtual digital space (DTs); to individual and to collective; to human development and technological development.

\footnotetext{
That reconcilement is not anachronistic, as it emerges that in invisible bonds of virtual trades there is something more than an economic dimension, more than the positivist quantification, more than the material infrastructure that guarantees social cohesion and that e have not finished measuring consequences. (MAFFESOLI, 2011, p. 20)
}

In this sense, we can rethink education, mainly the graduation processes of educators: through relationships promoted in those virtual digital spaces that are mediatized by every person, historical, social and cultural construction that sets the space. Thus, the 
acquaintanceship among people in virtual digital spaces (digital technologies) is resetting society as a whole, from relationships, interactions, associations and groupings between subjects and objects. Therefore, according to Latour (1991) the radiating focus is found in the action of the one who or that which makes the other do in the net. That one or that are not individualities, but interlaced branches; therefore, one cannot be explained without the other. However, those relationships may preserve (subject overcomes object), that Latour (1999) invites us to abandon this idealistic-realistic position, or transform (subject and object cohabit), understanding the dynamics game between local and global, the way of living together. That is, reproduce or produce culture, depending on how acquaintanceship will be constituted in the collectiveness.

\section{REFERENCES}

BACKES, Luciana. A configuração do espaço de convivência digital virtual: a cultura emergente no processo de formação do educador. 2011. $363 \mathrm{f}$. Tese (Doutorado em Educação) - Universidade do Vale do Rio dos Sinos, São Leopoldo, RS, 2011. Available in: <http://goo.gl/B96pV7>. Access in: 14 June. 2016.

BACKES, Luciana. Espaço de convivência digital virtual (ECODI): o acoplamento estrutural no processo de interação. Educação Temática Digital, Campinas, SP, v. 15, n. 01, p. 337355. mai./ago. 2013. Available in: 〈http://goo.gl/nSLZpO>. Access in: 14 June 2016. ISSN $1676-2592$.

BACKES, Luciana. O hibridismo tecnológico digital na configuração do espaço digital virtual de convivência: formação do educador. Inter-Ação, Goiânia, GO, v. 40, n. 03, p. 435 456. set./dez. 2015. Available in: 〈http://goo.gl/vfa4WV〉. Access in: 14 June 2016. ISSN 1981-8416.

BARDIN, Laurence. Análise de conteúdo. São Paulo: Edições 70, 2011.

COSTA, Rosmeri Ceconi. Interação em mundos digitais virtuais: uma investigação sobre a representação do emocionar na aprendizagem. 2008. 181 f. Dissertação (Mestrado em Educação) - Universidade do Vale do Rio dos Sinos, São Leopoldo, RS, 2008. Available in: <http://goo.gl/2wpGsx >. Access in: 14 June 2016.

FREIRE, Paulo, SHOR, Isa. Medo e ousadia: cotidiano do professor. Rio de Janeiro: Paz e Terra, 1992. Available in:: <http://goo.gl/0YdmAS>. Access in: 14 June 2016.

HUGON, Stéphane. Soudain: la technique. Les cahiers européens de l'imaginaire: technomagie, v. 03, n. 01, p. 62-69. 2011.

LATOUR, Bruno. Nous n'avons jamais été modernes, essai d'anthropologie symétrique. Paris: Éd. La Découverte, 1991.

LATOUR, Bruno. Politiques de la nature. Comment faire entrer les sciences en démocratie. Paris: Éd. La Découverte, 1999. 
LEMOS, André. Cibercultura: tecnologia e vida social na cultura contemporânea. Porto Alegre: Sulina, 2007.

LEMOS, André. Mobile communication and news sense of places: a critique of spatialization in cyberculture. Galáxia, São Paulo, SP, v. 16, n. 01, p. 91-108. dez. 2008. Available in: <http://goo.gl/H9oY0j>. Access in: 14 June 2016. ISSN 1982-2553.

LÉVY, Jacques ; LASSAULT, Michel. Dictionnaire de la géographie et de l'espace des sociétés. Paris: Belin, 2003.

MAFFESOLI, Michel. Le temps des tribus. Le déclin de l'individualisme dans les sociétés de masse. Paris : La Table Ronde, 2000.

MAFFESOLI, Michel. O imaginário é uma realidade. FAMECOS : mídia, cultura e tecnologia, Porto Alegre, RS, v. 15, n. 01, p. 74-82. ago. 2001. Available in: <http://goo.gl/ojFXsf >. Access in: 14 June 2016. ISSN 1980-3729.

MAFFESOLI, Michel. Perspectivas tribais ou a mudança do paradigma social. FAMECOS: mídia, cultuar e tecnologia, Porto Alegre, RS, v. 23, n. 01, p. 23-29. Abr. 2004. Available in: <http://200.144.189.42/ojs/index.php/famecos/article/view/364/295>. Access in: 14 June 2016. ISSN 1980-3729.

MAFFESOLI, Michel. Les mémoires des tribus et le ré-enchantement du monde. In:

CASALEGNO, Federico. Mémoire quotidienne: communautés et communication à l'ère des réseauxpp. Québec: Presses de l'Université Laval. p. 129-146.

MAFFESOLI, Michel. Comunidade de destino. Horizontes Antropológicos, Porto Alegre, RS, v. 12, n. 25, p. 273-283. jan./jun. 2006. Available in: 〈http://goo.gl/7NXVcP $\rangle$. Access in: 14 June 2016. ISSN 1806-9983.

MAFFESOLI, Michel. L'initiation au présent. Les cahiers européens de l'imaginaire: technomagie, v. 03, n. 01, p. 14-27. 2011.

MAFFESOLI, Michel. O tempo retorna: Formas elementares da pós-modernidade. Rio de Janeiro: Forense Universitária, 2012.

MATURANA, Humberto Romesín. Uma nova concepção de aprendizagem. Dois Pontos, Curitiba, PR, v. 15, n. 01, p. 28-35. 1993.

MATURANA, Humberto Romesín. Transformación en la convivência. Santiago de Chile: Dólmen Ediciones, 1999.

MATURANA, Humberto Romesín; VARELA, Francisco. A árvore do conhecimento: as bases biológicas da compreensão humana. São Paulo: Palas Athena, 2002. Available in: <http://goo.gl/UGBc4X >. Access in: 14 June 2016.

MORAES, Maria Cândida. Educar na biologia do amor e da solidariedade. Petrópolis: Vozes, 2003. 
SANTAELLA, Lúcia. A ecologia pluralista da comunicação: conectividade, mobilidade, ubiquidade. São Paulo: Paulus, 2010.

SANTOS, Milton. Por uma geografia nova: da crítica da geografia a uma geografia crítica. São Paulo: Editora HUCITEC, 1980.

SCHLEMMER, Eliane; MALIZIA, Pierfranco; MORETTI, Gaia et al. Comunidades de aprendizagem e de prática em metaverso. São Paulo: Cortez, 2012.

SOUZA; SILVA, Adriana. (2006). Do ciber ao híbrido: tecnologias móveis como interfaces de espaços híbridos. In: ARAÚJO, Denize Correa (Org.) Imagem (ir) realidade: comunicação e cibercultura. Porto Alegre: Sulina, 2006. p. 21-51.

LUCIANA BACKES

Pós doutoranda - CAPES - Université Paris Descartes - Paris V - Sorbonne Doutor em Educação - Universidade do Vale do Rio dos Sinos - UNISINOS - São

Leopoldo, RS

E-mail: luciana.backes@unilasalle.edu.br

CLEBER GIBBON RATTO Doutor em Educação - Pontifícia Universidade Católica do Rio Grande do Sul - PUCRS Professor e pesquisador - Centro Universitário La Salle - Unilasalle - Canoas, RS E-mail: cleber.ratto@unilasalle.edu.br

Recebido em: 15/12/2015 Aprovado para publicação em: 30/06/2016

Como citar este documento:

BACKES, Luciana; GIBBON RATTO, Cleber. The tribes in the context of the digital technological hybridism: the constitution of the virtual digital acquaintanceship. ETD - Educação Temática Digital, Campinas, SP, v. 18, n. 3, p. 564-579, ago. 2016. ISSN 1676-2592. Disponível em:

<http://periodicos.sbu.unicamp.br/ojs/index.php/etd/article/view/8646105>. Acesso em: 29 ago. 2016. doi:http://dx.doi.org/10.20396/etd.v18i3.8646105. 